\title{
Information systems evaluation: navigating through the problem domain
}

\author{
Zahir Irani* \\ Information Systems Evaluation and Integration Group (ISEIG), Department of Information Systems and Computing, \\ Brunel University, Uxbridge UB8 3PH, Middlesex, UK
}

Received 20 November 1999; accepted 22 August 2001

\begin{abstract}
Information systems (IS) make it possible to improve organizational efficiency and effectiveness, which can provide competitive advantage. There is, however, a great deal of difficulty reported in the normative literature when it comes to the evaluation of investments in IS, with companies often finding themselves unable to assess the full implications of their IS infrastructure. Although many of the savings resulting from IS are considered suitable for inclusion within traditional accountancy frameworks, it is the intangible and non-financial benefits, together with indirect project costs that complicate the justification process. In exploring this phenomenon, the paper reviews the normative literature in the area of IS evaluation, and then proposes a set of conjectures. These were tested within a case study to analyze the investment justification process of a manufacturing IS investment. The idiosyncrasies of the case study and problems experienced during its attempts to evaluate, implement, and realize the holistic implications of the IS investment are presented and critically analyzed. The paper concludes by identifying lessons learnt and thus, proposes a number of empirical findings for consideration by decisionmakers during the investment evaluation process.
\end{abstract}

(C) 2002 Elsevier Science B.V. All rights reserved.

Keywords: Investment justification; Evaluation; IT/IS; Case study

\section{Introduction}

The importance of developing a robust and responsive information technology (IT) and information system (IS) infrastructure to support the formal planning and control of business processes is increasing in importance. In support of this, Weill and Broadbent [55] draw attention to the care needed during the evaluation and management of technology-based resources. In particular, explaining that the management of

\footnotetext{
Fax: +44-1895-816-242.

E-mail address: zahir.irani@brunel.ac.uk (Z. Irani).

URL: http://www.brunel.ac.uk/ csstzni
}

investment in the capabilities of IT networks, people, data, and software may be one of the most important decisions taken by senior management regarding expenditure. Stratopoulos and Dehning [50] report empirical evidence that suggests the financial performance of a firm, is more related to the way IT assets are managed, than the level of organizational spending on new technology, and thus, adding further dimensions to the productivity paradox. Clearly, raising questions for organizations regarding the way that their IT investment portfolios are evaluated, managed, and controlled. Yet, the complexity of managing benefit intangibility and indirect costs remain as considerable research issues for management and academe to overcome. 
Wight [57] suggests that the use of information systems such as manufacturing resource planning (MRPII) within manufacturing organization are often the natural choice for improving process performance and organizational competitiveness. The reason for this is that such systems provide businesses with robust and responsive intra-organizational infrastructure; Irani et al. [30] draw attention to many of the human and organizational issues associated with its evaluation and management. Yet, as companies become more global and develop international supply chains, the limitations of MRPII have become apparent. Chung and Snyder [13] identify the attempt being made by many organizations to expand there IS infrastructure beyond their organizational boundaries through developing inter-organizational business systems. Consequently, this has resulted in the widespread adoption of enterprise resource planning (ERP) solutions, with Heald and Kelly [25] identifying a portfolio of reasons behind the predicted US\$ 72.63 billion market size of the ERP industry by the year end 2002. Yet, such systems are not infallible and without limitation, with Themistocleous and Irani [52] drawing attention to many of the integration problems being experienced by companies.

Regardless, limited empirical research has been reported on the evaluation of both intra- and interorganizational systems, possibly because few companies wish to publicize their difficulties and failures. It is in attempting to address this relative research void that the author attempted to navigate through the problem domain of IS evaluation. In doing so, presenting an intra-organizational perspective on the evaluation of MRPII, such that others can draw lessons and thus, develop appropriate plans for enabling, developing and better managing their IS infrastructure.

\section{The evaluation of information systems: issues and concerns}

The diverse problems associated with IS evaluation have been widely reported in the normative literature $[5,12,26,30,35,44,49]$. As a result, common themes that complicate IS evaluation can be readily extrapolated from the literature and includes:
- Understand the human and organizational mechanics of investment decision making within organizations.

- Enable a better 'technology-fit' and integration of business systems.

- Understand the concept of 'value' and its multidimensional facets.

- Assess the political issues associated with capital budgeting and decision making.

- Navigate through the taxonomies of investmentrelated benefits.

- Assess the natures of IT/IS benefits (intangible, tangible; financial and non-financial).

- Identify, manage and control investment-related costs (direct and indirect).

- Appreciate the portfolio of investment appraisal techniques.

- Assess the 'risks' associated with different investment-related strategies.

- Understand the scope and impact of developing a IT infrastructure.

- Appreciate the complexity of evaluating incremental system development, integration and upgrades.

- Stakeholders definition, analysis and involvement (inclusive culture).

- Provide appropriate technology management resources.

Hochstrasser [28] argues that the high rate of IT/IS failure is partly attributable to a lack of solid but easy to use management tools for evaluating, prioritizing, monitoring, and controlling IT investments. Voss [54] claims that technology-focused investments fail due to organizational problems, and identified economic justification as a significant contributing factor.

Hochstrasser and Griffiths [27] identified the overwhelming belief of many industries that they are faced with outdated and inappropriate procedures for investment appraisal, and that all responsible executives can do is to cast them aside in a bold 'leap of strategic faith'. Correspondingly, this investment strategy is advocated by the British CIMA/IProdE [14], which states that some benefits of IT/IS cannot be quantified, and as a result an act of faith approach may be necessary.

When the purpose of IT investments are to improve operational efficiency, many traditional appraisal techniques may be considered appropriate. Such 
investments are largely geared to the generation of tangible (financial) benefits, and are based on direct (financial) project costs. Such operational IT deployments have traditionally exploited the efficiency benefits of investing in IT. However, many managers are now appreciating the wider strategic implications of developing a robust and responsive IT infrastructure, yet this in turn presents businesses with the dilemma of how to assess, quantify and accommodate the implications of infrastructural investments within traditional methods of appraisal. Much of this concern centers on management's inability to develop robust and responsive plans to accommodate the impact of infrastructure-based investments. Indeed, it is necessary to recognize that organizations need to tailor existing evaluation methodologies to incorporate technology-related flexibility. In developing towards this process, $\mathrm{Li}$ and Chen [40] propose an empiricallyvalidated demand-centric adaptive IS planning framework, which can be used to aid management during the allocation of organizational resources for IT investments.

\section{Evaluating a manufacturing information system: conceptualization}

The evaluation of IT infrastructures may be regarded as the integration and management of business processes that controls the efficient and effective use of techno-based resources. In exploring this, researchers such as Serafeimidis and Smithson [46], and Khalifa et al. [36] have attempted to acknowledge the wide variety of drivers surrounding decision making. In doing so, approaching investment decision making from a non-traditional (paradigm shift) perspective. In expanding this approach further, the author proposes the development of an application specific evaluation model, which goes beyond the confines of traditional (generic) financial appraisal through integrating key business drivers.

Proposition 1. Specific evaluation criteria for manufacturing information systems would make the evaluation process more manageable.

It is expected that a robust evaluation model will help reduce the time needed to make IT investment decisions, by removing non-value adding activities and retaining project focus during the evaluation process. Hence, the proposed model integrates the characteristics, benefits, and costs associated with the IT application being considered by the organization, for example MRPII. Therefore, expands traditional project appraisal through identifying and describing those key management factors associated with developing technology-based solutions. Although there are a whole host of technology management issues that need consideration during investment decision making, this paper fills a relative void by focusing on three core factors:

- Distinguishing different types of justification processes;

o concept based;

$\circ$ financially based.

- Limitations inherent in traditional appraisal techniques.

- Life cycle evaluation.

\subsection{Concept justification}

The traditional investment justification process centers on the scrutiny of direct project costs such as those presented by Anandarajan and Wen [1], and Irani et al. $[32,33]$. Concept-based justification however, requires a softer more persuasive approach, and is one that is predominantly interpretivist in nature [11]. This approach is likely to be sought by those with executive responsibilities, and is one of aligning the projects' proposal with the medium/long-term strategic and financial business plan(s) of the company. It can also be expanded to those operational employees that are stakeholders of the system. Consequently, it may be used to communicate the issues and implications surrounding the adoption of new technology to either the project stakeholders, or larger population of the organization. Fig. 1 conceptualizes those stakeholders with an interest in this type of justification process.

Within, this approach directors and senior managers retain a strategic focus when analyzing the roles and effects of the IT investment. They have the responsibility for developing a long-term future plan for the organization, and need to foresee the relevance and positioning of such investments on the success and growth of the organization. Therefore, the concept 


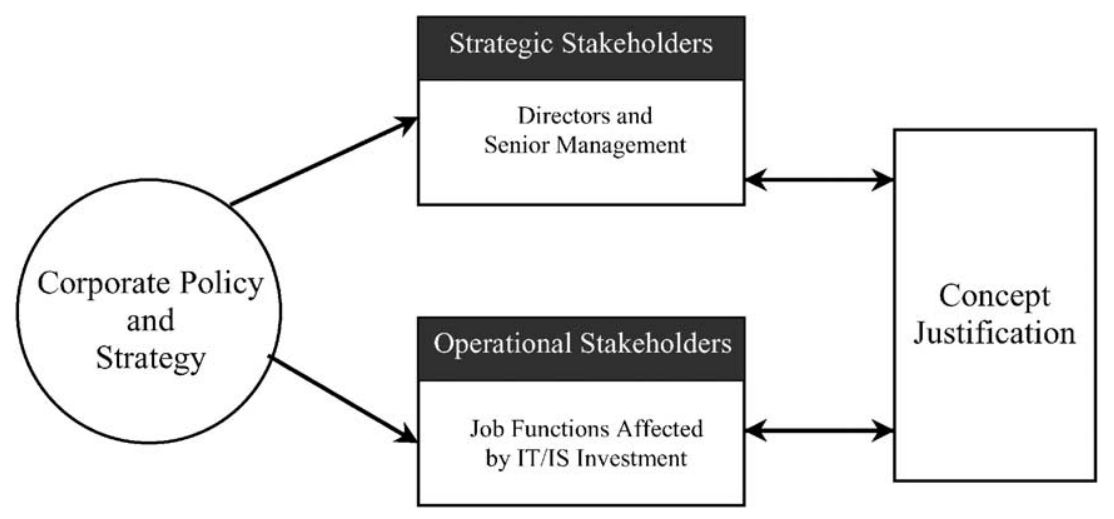

Fig. 1. Concept justification stakeholders.

justification of an IT/IS investment to its strategic stakeholders will have a strong alignment with the corporate strategy of the organization, and include competitive risks associated with not investing. The process of concept justification to senior management will also allow for a wider consideration of the holistic benefits (including portfolios and natures) and costs (direct and indirect) associated with the project, for examples that include MRPII see Irani and Love [31].

The involvement of operational stakeholders and employees will also help raise the importance and contribution of the investment, towards the organizations' growth and success. In doing so, raising the status of the investment proposal through sharing ownership. Therefore, concept justification may be considered integral to a robust IT evaluation process, with the following proposition being proffered.

Proposition 2. There is a relationship between the concept justification of an information system to operational stakeholders, and their increased level of commitment towards project success.

\section{Financial justification}

Traditional appraisal procedures include the setting of project costs (direct) against quantifiable savings and benefits predicted to be achievable. Boaden and Dale [6] suggest that senior management will want to understand the financial implications of their IT investments, and its resulting impact on the organization. However, the vast array of appraisal methods
$[29,45]$ leaves many organizations with the quandary of deciding which to use, if any. During the financial justification process of an intra-organizational system, for example MRPII, the primary concern is with the individual pieces of technology that needs to be bought, linked, and integrated. Typical links include those between remote 'off-line' part programming and computer numerically controlled (CNC) machinery. Hence, financial justification may include an identification of the integration links that are required. The stakeholders active during the financial justification process are shown in Fig. 2.

\subsection{Limitations of traditional appraisal techniques}

Investments in systems such as MRPII offer many business benefits and savings that can be accommodated within traditional accountancy frameworks. Yet, Aggarwal [2], Farbey et al. [20], and Lefley and Sarkis [39] suggest that management has difficulty in quantifying many of the 'softer' benefits of IT/IS. However, others, such as Primrose $[42,43]$ argue that all resulting benefits can and should be quantified in financial terms. Consequently, large numbers of companies find the evaluation process confusing, and without consensus on what constitute meaningful evaluation thus, supporting their widespread abandonment of investment appraisal technique [48].

Regardless, Ballatine and Stray [3,4], and Lefley [38] report the use of traditional appraisal techniques during the evaluation of IT although, argue that such methods have become obsolete and inappropriate. 


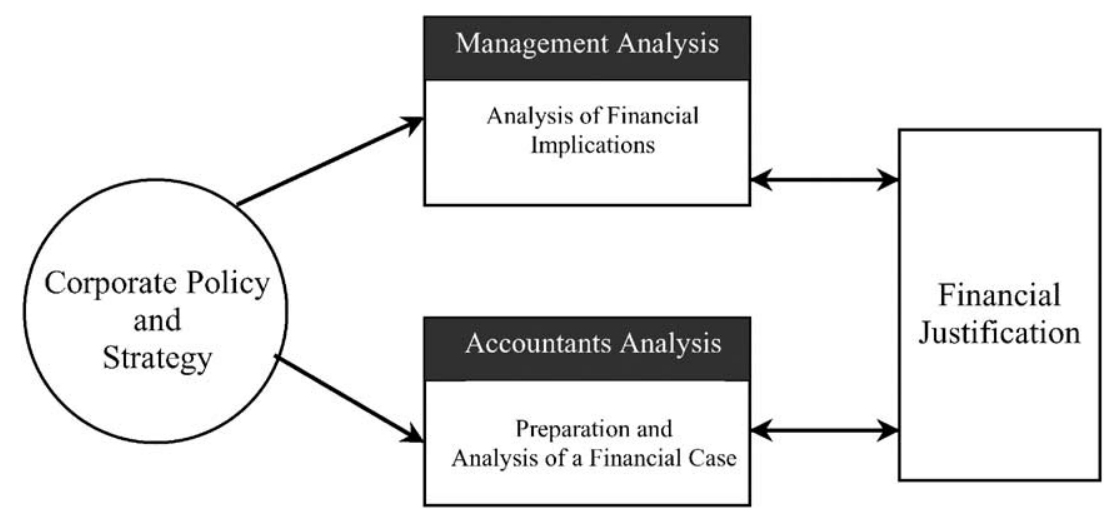

Fig. 2. Financial justification stakeholders.

In doing so, discouraging long-term strategically important projects that typically offer intangible and non-financial benefits. Interestingly, Van Blois [53] suggests that many managers have become preoccupied with financial appraisal. Inevitably resulting in many long-term important projects failing to pass the appraisal process irrespective of their strategic impact. Interestingly, Hochstrasser [28] proposes an interesting correlation between project failure and a lack of an easy to use project management tool for evaluating, prioritizing, monitoring, and controlling investments.

\section{Life cycle evaluation}

Hamilton [24] suggests that post-implementation evaluation, when positioned as part of a life-cycle evaluation process may result in beneficial outcomes that include:

- Improvements in subsequent system development practice.

- Decisions to adopt, modify, or discard IS.

- Evaluation of personnel responsible for system development, implementation and operation.

However, Green and Kiem [22] highlight:

- Ensured compliance with user objectives.

- Improvements in the effectiveness and productivity of the design.

- Cost savings through modifying the system during implementation, before, rather than after, complete integration.
Clearly, a comprehensive post-implementation review process would appear to be value adding, and support organizational learning and a 'deeper' understanding of the IT infrastructure. However, Ezingeard and Race [18], Ezingeard et al. [19], and Kumar [37] suggest it is seldom performed in practice.

Assessing IT value within an organization has consistently ranked as one of management's top concerns [8,38]. In addressing this from a MRPII perspective, Wight [56] proposes the use of a checklist that defines implementation success: a grade is awarded post-implementation to the company, depending upon the answers supplied to the checklist. Table 1 provides a summary of user characteristics.

Hence, the following propositions relate to MRPII benefits and costs that are well placed as appropriate benchmarks during the justification process.

Proposition 3. The scope of benefits and costs used to justify MRPII are restricted by mechanisms available within the organization to quantify such indicators.

Proposition 4. There is a need to classify the benefits of MRPII into strategic, tactical and operational benefits, and further sub-classify each category financially, non-financially and intangibly.

\section{Research methodology}

Considering the scope, sensitivity and depth of this research, a case study strategy was adopted $[7,23,58]$. However, the case used was not systematically 
Table 1

Oliver Wight classes A-D; user characteristics ${ }^{\mathrm{a}}$

\begin{tabular}{|c|c|c|}
\hline Oliver Wight classification & Planning and control processes & Continuous improvement process \\
\hline Class A & $\begin{array}{l}\text { Effectively used company-wide; generating } \\
\text { significant improvements in customer service, } \\
\text { productivity, inventory and costs }\end{array}$ & $\begin{array}{l}\text { Continuous improvement has become a way-of life } \\
\text { for employees, suppliers and customers; improved } \\
\text { quality, reduced costs and inventory are contributing } \\
\text { towards a competitive advantage }\end{array}$ \\
\hline Class B & $\begin{array}{l}\text { Supported by top management; used by middle } \\
\text { management to achieve measurable company } \\
\text { improvements }\end{array}$ & $\begin{array}{l}\text { Most departments participating and active involvement } \\
\text { with suppliers and customers; making substantial } \\
\text { contributions in many areas }\end{array}$ \\
\hline Class C & $\begin{array}{l}\text { Operated primarily as better methods for ordering } \\
\text { materials; contributing to better inventory } \\
\text { management }\end{array}$ & $\begin{array}{l}\text { Processes utilized in limited areas; some departmental } \\
\text { improvements }\end{array}$ \\
\hline Class D & $\begin{array}{l}\text { Information inaccurate and poorly understood by } \\
\text { users; providing little help in running the business }\end{array}$ & Processes not established \\
\hline
\end{tabular}

${ }^{\mathrm{a}}$ Wight [56]: the Oliver Wight classes A-D checklist for operational excellence.

sampled, therefore it is not possible to generalize findings to a wider population of companies. Regardless, constants in process and outcome can be drawn by others, and used as a means of navigating through the evaluation process.

\subsection{Data collection}

The data collection procedure followed the norms of fieldwork research (e.g. [15,21]). A variety of data sources were used that included findings from interviews, observations, illustrative materials (e.g. newsletters and other publications of the organization's history), and past project documentation. Secondary data sources were also used, such as internal reports, budget reports, and filed accounts. The author used his experience in industry, together with a predefined interview protocol, to generate determine the data needed $^{1}$ to navigate the interview process.

\subsection{Interviews}

Interviews were conducted with the managing director, production director, production manager, and shop floor employees. The duration of each interview was approximately $40 \mathrm{~min}$ and conducted on a one-to-one basis. The author acted as a neutral med-

\footnotetext{
${ }^{1}$ There were no specific preset questions but rather an interview agenda format was adopted.
}

ium through which questions and answers were transmitted and therefore, trying to eliminate data bias. Often, interviewer bias results from the use of probes, follow-up questions, that are used to get respondents to elaborate on ambiguous, or incomplete answer [47]. Hence, such factors were avoided to increase the reliability of data generated.

In trying to clarify the respondent's answers, the interviewer was careful not to introduce any new ideas, and was mindful of the feedback that respondents gained: the interviewer avoided giving overt signals, such as smiling and nodding.

\subsection{Case study validity}

The use of interviews, documentary sources, and observations suggest that internal validity must be addressed. Each interview was taped recorded and subsequently transcribed. These were returned to each interviewee to check and resolve any discrepancies. Consequently, care was undertaken to ensure that the data collected converged on similar facts, as described by Jick [34].

\subsection{Background to case study organization}

Company V produces small quantities of a wide variety of made-to-order parts, products, and assemblies for a large number of customers in diverse industries. In effect, it sells time and expertise using 
many different conventional and computer-controlled machines; in the products and assemblies it manufactures, there are few common components.

To produce differing and often complex parts, frequently on short notice, and to satisfy the competitive environment, a highly flexible production capability is required. Orders for individual products are sometimes small and their timing depends on the fluctuating needs of customers who use the company to off-load capacity and reduce inventory cost, etc. Close communication links between company and customer are necessary to adapt to the necessary changes. An executive VP, whose functions are sales and marketing, reports to the president. There is also a finance VP, an administrative VP to whom the purchasing and human resource functions report, an engineering VP to whom IT reports, and a manufacturing director (MD). On the shop floor there are supervisors that direct teams of 7-15 staff members, such as machine operators, assemblers, material handlers, receivers, shippers, etc.

\section{Research findings}

The MD realized that suitable production planning and control (PPC) systems needed to be implemented to sustain and develop the company's growth. Company V's lack of formal justification centered on having only previously invested in projects that could be appraised using traditional methods. In particular, major strategic benefits from PPC, such as perceived market leadership, and promotion of an open culture, although acknowledged as extremely important to the growth and survival of the firm, were not readily converted into cash values.

Previous investments had been financed through loan agreements, where cash flow projections and sensitivity analysis had been used to assess the impact and risk of the investment. However, company V soon discovered that such frameworks were not suitable for investments that had intangible and non-financial benefits, and indirect costs. This issue, together with a new and inexperienced management team that was unaware of emerging appraisal techniques that could acknowledge, albeit subjectively, indirect costs and benefits, resulted in a simplistic cost/benefit analysis (CBA) being used. Management's use of CBA allowed the listing of perceived project benefits and costs, however there was no arbitrary or otherwise assignments of financial values.

Table 2 presents taxonomies of benefits in company V's CBA. This taxonomy has been categorized into: strategic, tactical, and operational benefits. These have then been sub-classified as: financial, non-financial, and/or intangible.

Company V's CBA only identified direct financial costs, such as those presented in the taxonomy of Irani et al. [32,33]. Therefore, as company V was unable to calculate the financial returns due to the portfolio of intangible benefits and indirect costs, an act of faith decision was taken by the management team.

A software selection and implementation team was assembled, and included management operatives from a number of organizational functions. System requirement objectives were identified, with this group responsible for ensuring that the selected system (COTS) was able to operate within the parameters of British Standard 5750:ISO 9002 [9], and within the operating procedures of the company. The minor reengineering of business processes was considered acceptable and inevitable. After attending two manufacturing software trade exhibitions, a suitable software vendor was identified, Vendor K.

When asked to elaborate on the justification for selecting Vendor K, the production of route cards that detailed machine operations; machine run, and set-up times as well as quality standard checks, were all identified as key criteria. Interestingly, a subsequent check confirmed that Vendor K had sold over 100 site licenses of COTS, which acted as a further motivator to select this vendor.

During the implementation of the core PPC modules, it became evident that the COTS required data to 'fit' its needs, rather than it being possible to adjust the way that company $\mathrm{V}$ operated. These appeared to be significant cost factors that had not been included in the CBA, and as a result appeared as significant indirect cost factors.

The PPC system proved more difficult than anticipated. For the first time, company $\mathrm{V}$ had discipline, controls and procedures, within their PPC system, producing route cards and operational planning with full product tractability. However, the production manager was regularly confronted with production schedules that had enormous amounts of seemingly meaningless data, and was ready to go back to the old 
Table 2

Taxonomy of benefits considered as part of cost/benefit/value analysis

\begin{tabular}{|c|c|c|c|}
\hline Classification of MRPII benefits & Financial & Non-financial & Partly/totally intangible \\
\hline \multicolumn{4}{|l|}{ Strategic benefits } \\
\hline Improved growth and success & $\checkmark$ & $\checkmark$ & $\checkmark$ \\
\hline Leader in new technology & & & $\checkmark$ \\
\hline Improved market share & $\checkmark$ & & \\
\hline Market leadership & $\checkmark$ & $\checkmark$ & $\sqrt{ }$ \\
\hline Enhanced competitive advantage & $\checkmark$ & $\sqrt{ }$ & $\checkmark$ \\
\hline \multicolumn{4}{|l|}{ Tactical benefits } \\
\hline Improved flexibility & $\checkmark$ & $\checkmark$ & $\checkmark$ \\
\hline Improved response to changes & & $\checkmark$ & \\
\hline Improved product quality & $\checkmark$ & $\checkmark$ & $\sqrt{ }$ \\
\hline Improved organizational teamwork & & & $\checkmark$ \\
\hline Promotes concept of open culture & & & $\checkmark$ \\
\hline Improved integration with other business functions & & & $\checkmark$ \\
\hline Increased productivity & $\checkmark$ & & \\
\hline Increased plant efficiency & $\checkmark$ & & \\
\hline Reduced delivery lead-times & & $\checkmark$ & \\
\hline Reduced manufacturing lead-times & & $\checkmark$ & \\
\hline Improved capacity planning & $\checkmark$ & $\checkmark$ & $\checkmark$ \\
\hline Improved stability of MPS & & $\checkmark$ & \\
\hline Improved data management & & $\checkmark$ & $\checkmark$ \\
\hline Improved manufacturing control & & $\checkmark$ & $\checkmark$ \\
\hline Improved accuracy of decisions & $\sqrt{ }$ & $\checkmark$ & $\sqrt{ }$ \\
\hline \multicolumn{4}{|l|}{ Operational benefits } \\
\hline Reduced raw material inventory & $\checkmark$ & & \\
\hline Reduced levels of WIP & $\checkmark$ & & \\
\hline Reduced labor costs & $\checkmark$ & & \\
\hline Reduced manufacturing costs & $\checkmark$ & & \\
\hline Increased throughput & $\checkmark$ & & \\
\hline Improved data availability and reporting structure & & & $\checkmark$ \\
\hline Improved communication through 'on-line' order progressing & & & $\checkmark$ \\
\hline Improved product tractability & & & $\checkmark$ \\
\hline Formalized procedures with accountability and responsibility & & & $\checkmark$ \\
\hline Improved schedule adherence & $\checkmark$ & $\sqrt{ }$ & $\checkmark$ \\
\hline
\end{tabular}

manual way of production control. However, the production manager was eventually convinced that the computerized PPC was a sensible way forward. The team explained that the difficulties being experienced were due to a lack of suitable reporting structures and data format. Moreover, it was thought that the system needed time to 'settle down'.

There was no alignment between the investment in Vendor K's software and the company's business plan. For company $\mathrm{V}$, the biggest problem was that any 'hitch' in data recording, or its accuracy, caused the system to become highly unstable. Therefore, the implementation team investigated the purchase of Vendor K's shop floor documentation (SFD) module.
This was sought to improve data accuracy and subsequent schedule stability, so that PPC resource decisions could be better taken thus, improving the systems' integrity. Furthermore, the purchase of the SFD module seemed a natural progression towards achieving full MRPII integration [57].

After a successful pilot, shop floor employees installed 6 bar code reading units. This 'on-line' process continuously updated the weekly production schedule, and would ensure consistently accurate information on capacity availability and job statuses. After extensive use, shop floor users were informally questioned about the effectiveness of the bar code reading units. The consensus was that the terminals do 
not work reliably. Many were regularly out of order, with the system apparently unable to work with dirt, grease and oil contaminants. However, the pilot study that ran a single bar code reader proved to be effective, showing $95 \%$ data accuracy.

In addition, none of the operational workforce had been educated on the importance of PPC or the contribution that SFD can make to the performance of the PPC function. Management further attributed a lack of education and training to poor support of the system amongst its stakeholders. These factors had a significant impact on the success of the PPC and SFD module, and were not acknowledged as issues during the ad hoc evaluation of the PPC system.

\subsection{The development of bespoke intra- organizational system}

Increasingly, members of the management team questioned the need for the COTS software, which had fixed bureaucratic reporting structures and demanded the reengineering of business processes. As a result, management, supported by the software selection and implementation team, advocated the development of a bespoke MRPII system, which would be based around the idiosyncrasies of company V. The previously formed software selection and implementation team sought to justify the new system development of MRPII. They thought that the company would be more satisfied with their 'own' system, rather than COTS. Interestingly, Burns et al. [10] suggests that companies that develop their own software are more satisfied with the results.

Table 3 presents a taxonomy that culminates indirect organizational and human costs associated with the adoption of COTS and development of a bespoke system. Examples of these cost factors have then been identified and classified as financial and/or intangible.

Acknowledging failure, company $\mathrm{V}$ decided to abandon the use of Vendor K's SFD module. This was a result of:

- Low data reliability.

- Hardware terminal problems.

- Lack of employee support and discipline in the use of the bar code system.

- Lack of interest in continuing the implementation process.
- Misalignment of the strategic direction of the vendor and the organization.

- Fall in productivity.

- Lack of clear project focus, leadership, and deliverables. The company went back to basics and drew on their experience.

The MD decided to enlist the support of a consultancy company to facilitate the design, development, and implementation of a bespoke MRPII system. However, first, company $\mathrm{V}$ reassessed its strategic direction, organizational strengths and weaknesses, revised its business plan, and developed a project strategy: under the support of a consultant that was partially funded under a government scheme.

Company V then identified and defined a series of intensive educational sessions and workshops, which were planned in detail and spread over several months to ensure employee and management attention was maintained. Incidentally, company V subscribed to the notion of the attention economy that is discussed by Davenport and Beck [16]. All functional managers were educated on the importance of MRPII, and on the impact that the investment would make to their job. From a management perspective, managers were also briefed on the need for enthusiasm and were set short milestones and deliverables to ensure attention was retained.

A simplified concept justification course was developed for shop floor stakeholders. This not only addressed their educational needs but also looked at the practical implications of the system on their jobs. Teamwork was promoted with all employees being mixed and grouped together. They were filmed and reviewed playing fun to learn games, using 'Lego' and 'jigsaws', all with meaning for throughput production flow, communication, Just in tme, inventory management, and total quality management. The workshop exercises appeared to be well received and helped in winning over skeptics.

The new system was essentially built on the foundations of a fourth generation relational database language, whilst also utilizing the core PPC module: production control and scheduling (PCS) part. The function of the PPC module was essentially for scheduling purposes.

The team decided not to integrate the SFD module, for fear of further complicating the development and 
Table 3

Taxonomy of costs considered as part of bespoke cost/benefit analysis

\begin{tabular}{|c|c|c|c|}
\hline Classification of MRPII costs & MRPII cost factor & Financial & $\begin{array}{l}\text { Partly/totally } \\
\text { intangible }\end{array}$ \\
\hline \multicolumn{4}{|l|}{ Indirect human costs } \\
\hline Cost of ownership: system support & Vendor support/trouble shooting costs & $\sqrt{ }$ & \\
\hline Management/staff resource & $\begin{array}{l}\text { Integrating computerized production planning } \\
\text { and control into work practices }\end{array}$ & $\checkmark$ & $\checkmark$ \\
\hline Management time & $\begin{array}{l}\text { Devising, approving and amending IT } \\
\text { and manufacturing strategies }\end{array}$ & $\checkmark$ & \\
\hline Management effort and dedication & $\begin{array}{l}\text { Exploring the potential of the system for } \\
\text { example linking and integrating new } \\
\text { systems together, e.g. CAM, DNC, CIM }\end{array}$ & $\checkmark$ & $\checkmark$ \\
\hline Employee time & $\begin{array}{l}\text { Detailing, approving and amending the } \\
\text { computerization of product BOMs }\end{array}$ & $\checkmark$ & \\
\hline Employee training & $\begin{array}{l}\text { Being trained to manipulate vendor software } \\
\text { and training others }\end{array}$ & $\checkmark$ & \\
\hline Employee motivation & $\begin{array}{l}\text { Interest in computerized production planning } \\
\text { and control reduces as time passes }\end{array}$ & & $\checkmark$ \\
\hline Changes in salaries & Pay increases based on improved employee flexibility & $\sqrt{ }$ & \\
\hline Staff turnover & $\begin{array}{l}\text { Increases in interview costs, induction costs, training } \\
\text { costs based in the need for skilled human resource }\end{array}$ & $\checkmark$ & \\
\hline \multicolumn{4}{|l|}{ Indirect organizational costs } \\
\hline $\begin{array}{l}\text { Productivity losses and } \\
\text { organizational impact }\end{array}$ & $\begin{array}{l}\text { Developing and adapting to new systems, } \\
\text { procedures and guidelines }\end{array}$ & $\checkmark$ & $\checkmark$ \\
\hline Strains on resource & $\begin{array}{l}\text { Maximizing the potential of the new technology } \\
\text { through integrating information flows and } \\
\text { increasing information availability }\end{array}$ & & $\checkmark$ \\
\hline Business process reengineering & $\begin{array}{l}\text { The re-design of organizational functions, } \\
\text { processes and reporting structures }\end{array}$ & $\checkmark$ & $\checkmark$ \\
\hline Security software protection & $\begin{array}{l}\text { The continuous need to upgrade security software } \\
\text { to overcome hacking and other external attacks } \\
\text { - viruses: this cost was seen as increasing and } \\
\text { never ending with the need for many upgrades }\end{array}$ & $\sqrt{ }$ & \\
\hline Security breaches & $\begin{array}{l}\text { Loss of time and the need to recover data and morale: } \\
\text { there is also the cost of litigation threats from suppliers } \\
\text { and customers, fraud, data theft, loss of productivity } \\
\text { and system damage and corporate trust }\end{array}$ & & $\sqrt{ }$ \\
\hline Organizational re-structuring & Covert resistance to change & & $\sqrt{ }$ \\
\hline
\end{tabular}

implementation process. During the development of there is infrastructure, company V schematically mapped out their entire business process using static flowcharting tools and in doing so, eliminating nonvalue adding processes.

\section{Case study analysis}

\subsection{Proposition 1: MRPII evaluation criteria}

The use of a descriptive application-specific evaluation framework would appear to have been appropriate during company V's development of an initial IT infrastructure. Indeed, it could be argued that company V's reliance on an ad hoc CBA was judgmental and subjective, with its lack of robustness and depth resulting in the system being abandoned and later deemed a failure. Although strategic, tactical, and operational benefits were identified as achievable, it would appear that company $\mathrm{V}$ took a myopic view of the project costs associated with the adoption of vendor PPC software. Furthermore, human issues had a significant impact on the adoption and acceptance of vendor software. However, such a learning 
experience proved invaluable and significantly supported the successful development and implementation of a bespoke MRPII system. Hence, in providing focus and depth of analysis, specific evaluation criteria would appear to make the evaluation process more manageable.

\subsection{Proposition 2: stakeholders during concept and financial justification}

The case experience appears to support findings that suggest the increased significance of human factors in the development of an intra-organizational infrastructure. Lack of stakeholder support appeared due to poor consultation and participation (including education and training) of stakeholders during the decision making and evaluation. Stakeholder involvement and inclusiveness was later sought to break down departmental barriers, with workshop exercises being developed to demonstrate efficient and effective resource planning during bespoke development. Such training and education sessions were later considered fundamental to the success of the project. Once all operational employees had been trained and educated, enthusiasm, ideas and commitment to replace the 'failed' vendor system began to develop. This resulted in a 'successful' bespoke system, confirming Proposition 2, that there is a relationship between the concept justification of an information system to operational stakeholders, and their increased level of commitment towards project success.

\subsection{Proposition 3: scope of benefits and costs}

During company V's initial CBA, lists of benefits sought were established. This portfolio was largely operational in nature, although strategic and tactical benefits were identified, as presented in Table 2 . These costs originally identified were limited to those 'visible' and financially quantifiable (direct). However, when additional costs were realized, for example, reengineering of processes, the information system was seen as causing chaos, with the view that the costs were spiraling out of control. Hence, indirect project costs would appear significant and yet, more retrospective in identification and analysis. Hence, findings from the case study appear to support the proposition that there is no relationship between the measurement of specific benefit, and the use of those benefits during MRPII justification. However, the scopes of costs identified was initially limited to those that are financially quantifiable (direct).

\subsection{Proposition 4: classification of costs}

The notion of benefit taxonomies is not new, for example $[12,17,30,31,41,51]$. The appraisal method used by company $\mathrm{V}$ supported a range of financial benefits that translated into project deliverables. Yet, some of the strategic benefits identified by company $\mathrm{V}$ were intangible in nature. Tactical benefits were financial, non-financial and intangible in nature. Hence, there is evidence to support the proposition that MRPII benefits can be classified into strategic, tactical and operational benefits, with financially, non-financially and intangibly natures.

\section{Conclusions}

Investment decision making remains a complex management process, largely due to the scope and magnitude of interacting socio-technical variables, which cannot always be quantified, in financial terms. However, irrespective of the scope and sensitivity of the IT/IS investment, the author of this paper has highlighted the importance of robust investment evaluation. In doing so, advocating benefit and cost management and thus, suggesting their identification and classification that in turn, supports their control and management. In exploring, the phenomenon of IT/ IS evaluation, the author proposed a number of theoretical conjectures that were tested within the confines of a case study. In doing so, it was possible to test such hypotheses and draw conclusions. As a result, the following empirical finding are offered:

- A case has been presented for the identification of application specific (for example MRPII) evaluation criteria, as opposed to generic evaluation methods. In doing so, increasing the focus and depth of evaluation analysis, which in turn supports increased manageability and project success.

- This paper has empirically demonstrated that there is a relationship between the concept justification of an information system to operational stakeholders, 
and their increased level of commitment towards project success.

- Indirect project costs are often more significant than their direct project cost counterpart, and can be classified as having human and organizational dimensions.

- Indirect costs are also considered to be retrospective in identification and analysis, and often spiral out of control.

- There is empirical evidence to suggest that there is no relationship between the measurement of specific benefit, and the use of those benefits during the justification process.

- Evidence has been offered to support the proposition that IT/IS benefits can be classified into strategic, tactical and operational benefits, with financially, non-financially and intangibly natures.

- A need has been identified to ensure management and employee attention is maintained during the IT/IS adoption process. The reason for this is that managers are often bombarded with requests for attention which needs careful management.

- There are a wide variety of interacting social and technical factors that complicate the evaluation process. This in turn makes the search for an integrated generic technique impossible.

\section{Acknowledgements}

The author would like to thank the case study for its participation in this project. Without its cooperation and support from management and employees this research could not have been undertaken. The author is also most grateful to the two anonymous referees and editor of Information and Management for their helpful constructive comments, which improved this manuscript. Finally, the author would like to acknowledge the financial support provided by the Engineering and Physical Sciences Research Council (EPSRC) Grant Ref.: [GR/M95066] and [GR/R08025].

\section{References}

[1] A. Anandarajan, H.J. Wen, Evaluation of information technology investment, Management Decision 37 (4), 1999, pp. 329-337.
[2] R. Aggarwal, Justifying investments in flexible manufacturing technology: adding strategic analysis to capital budgeting uncertainty, Managerial Finance 17 (2/3), 1991, pp. 77-88.

[3] J. Ballatine, S. Stray, Financial appraisal and the IS/IT investment decision making process, The Journal of Information Technology 13 (1), 1998, pp. 3-14.

[4] J. Ballatine, S. Stray, Information systems and other capital investments: evaluation practice compared, Logistics Information Management 12 (1-2), 1999, pp. 78-93.

[5] J. Bessant, Managing Advanced Manufacturing Technology: The Challenge of The Fifth Wave, NCC Blackwell, UK, 1991.

[6] R. Boaden, B. Dale, Justification of computer-integrated manufacturing: some insights into the practice, IEEE Transactions on Engineering Management 37 (4), 1990, pp. 291-296.

[7] T.V. Bonoma, Case research in marketing: opportunities, problems, and a process, Journal of Marketing Research 12 (1), 1985, pp. 199-208.

[8] J.C. Brancheau, J.C. Wetherbe, Key issues for information systems management, MIS Quarterly 11 (1), 1987, pp. 23-45.

[9] British Standards Institute (BSI), British Standard 5750 (2): Quality Systems, BSI, Linford Wood, Milton Keynes, UK, 1987.

[10] O.M. Burns, D. Turnipseed, W.E. Riggs, Critical success factors in manufacturing resource planning implementation, International Journal of Operations and Production Management 11 (4), 1991, pp. 5-19.

[11] G. Burrell, G. Morgan, Sociological Paradigms and Organizational Analysis, Heinemann, UK, 1979.

[12] I.J. Chen, M.H. Small, Implementing advanced manufacturing technology: an integrated planning model, International Journal of Management Science (Omega) 22 (1), 1994, pp. 91-103.

[13] S.H. Chung, C.A. Snyder, ERP adoption: a technological evolution approach, International Journal of Agile Management Systems 2 (1), 2000, pp. 24-32.

[14] CIMA/IProdE, Justifying Investments in Advanced Manufacturing Projects, Kogan Page, UK, 1987.

[15] F.C. Dane, Research Methods, Brooks/Cole, Pacific Cole, CA, USA, 1990.

[16] T.H. Davenport, J.C. Beck, The Attention Economy: Understanding the New Currency of Business, Harvard Business School Press, Boston, USA, 2001.

[17] J.G. Demmel, R.G. Askin, A multi-objective decision model for the evaluation of advanced manufacturing system technology, Journal of Manufacturing Systems 11 (3), 1992, pp. 179-194.

[18] J.-N. Ezingeard, P. Race, A survey of current practice of value assessment in the management of manufacturing information and data systems, in: Proceedings of the second International Conference on Management Integrated Manufacturing, 26-28 June, Leicester University, UK, 1996, pp. $407-414$.

[19] J.-N. Ezingeard, Z. Irani, P. Race, Assessing the value and cost implications of manufacturing information and data systems: an empirical study, European Journal of Information Systems 7 (4), 1999, pp. 252-260. 
[20] B. Farbey, F. Land, D. Targett, IT Investment: A Study of Methods and Practices, Management Today, ButterworthHeinemann Ltd., UK, 1993.

[21] J. Fiedler, Field Research: A Manual for Logistics and Management of Scientific Studies in Natural Settings, JosseyBass, San Francisco, USA, 1978.

[22] G.I. Green, R.T. Kiem, After implementation what's next? Evaluation, Journal of System Management 34 (9), 1983, pp. $10-15$.

[23] C. Hakim, Research Design: Strategies and Choice in the Design of Social Research, Allen and Unwin, London, UK, 1987.

[24] J.S. Hamilton, A survey of data processing post-installation evaluation practices, MIS Research Centre Working Paper, MISRC-WP-80-06, University of Minnesota, USA, 1980.

[25] K. Heald, J. Kelly, ARM Research Predicts ERP Market will Reach US\$ 72.63 billion by 2002, ARM Research, 2 November 1998.

[26] M.T. Hides, Z. Irani, P.E.D. Love, Supporting investment evaluation and project management: framework of IT/IS costs, in: Proceedings of the International Conference on Systems Thinking in Management, 8-10 November, Deakin University Waterfront Campus, Geelong, Australia 2000, pp. 240-244.

[27] B. Hochstrasser, C. Griffiths, Controlling IT Investment Strategy and Management, Chapman \& Hall, UK, 1991.

[28] B. Hochstrasser, Justifying IT investments, in: Proceedings of the Advanced Information Systems Conference, The New Technologies in Today's Business Environment, London, UK, 1992, pp. 17-28.

[29] Z. Irani, Developing an evaluation frame of reference through taxonomies of appraisal techniques and benefits, European Journal of Information Systems, in press.

[30] Z. Irani, A.M. Sharif, P.E.D. Love, Transforming failure into success through organizational learning: an analysis of a manufacturing information system, European Journal of Information Systems 10 (1), 2001, pp. 55-66.

[31] Z. Irani, P.E.D. Love, The propagation of technology management taxonomies for evaluating investments in information systems, Journal of Management Information System 17 (3), 2001, pp. 161-177.

[32] Z. Irani, J.-N. Ezingeard, R.J. Grieve, Costing the true costs of IT/IS investments: a focus during management decision making, The Journal of Logistics Information Management 11 (1), 1998, pp. 38-43.

[33] Z. Irani, J.-N. Ezingeard, R.J. Grieve, Integrating the costs of an IT/IS infrastructure into the investment decision making process, The International Journal of Technological Innovation and Entrepreneurship (Technovation) 17 (11/12), 1997, pp. 637-647.

[34] T.D. Jick, Mixing qualitative and quantitative methods: triangulation in accumulation, Administrative Science Quarterly 24, 1979, pp. 602-611.

[35] R.S. Kaplan, Yesterday's accounting undermines production, Harvard Business Review 62 (4), 1984, pp. 95-101.

[36] G. Khalifa, Z. Irani, L.P. Baldwin, Evaluating information systems in the private sector: association for information system, in: Proceedings of the Americas Conference on Information Systems (AMCIS 2001) (CD Proceedings), 3-5 August, Boston, MA, USA, 2001.

[37] K. Kumar, Post-implementation evaluation of computerbased information systems, Communications of the ACM 33 (2), 1990, pp. 203-212.

[38] F. Lefley, Capital investment appraisal of manufacturing technology, International Journal of Production Research 32 (12), 1994, pp. 2751-2756.

[39] F. Lefley, J. Sarkis, Short-termism and the appraisal of AMT capital projects in the US and UK, International Journal of Production Research 35 (2), 1997, pp. 341-368.

[40] E.Y. Li, H.-G. Chen, Output-driven information systems planning: a case study, Information and Management 38 (3), 2001, pp. 100-185.

[41] A. Money, D. Tromp, G. Wegner, The quantification of decision support benefits within the context of value analysis, MIS Quarterly 12 (2), 1988, pp. 223-236.

[42] P.L. Primrose, Selecting and evaluating cost-effective MRP and MRPII, International Journal of Operations and Production Management 10 (1), 1990, pp. 51-66.

[43] P.L. Primrose, Investment in Manufacturing Technology, Chapman \& Hall, UK, 1991.

[44] D. Remenyi, A. Money, M. Sherwood-Smith, Z. Irani, The effective measurement and management of it costs and benefits, Butterworth Heinemann/Computer Weekly, Second Edition, Professional Information Systems Text Books Series, UK, 2000.

[45] T.J.W. Renkema, E.W. Berghout, Methodologies for information-systems investment evaluation at the proposal stage: a comparative review, Information and Software Technology 39 (1), 1997, pp. 1-13.

[46] V. Serafeimidis, S. Smithson, Information systems evaluation in practice: a case study of organizational change, Journal of Information Technology 15 (2), 2000, pp. 93-106.

[47] J.J. Shaughnessy, E.B. Zechmeister, Research Methods in Psychology, 3rd Edition, McGraw Hill, Boston, USA, 1994.

[48] M.H. Small, J. Chen, Investment justification of advanced manufacturing technology: an empirical analysis, Journal of Engineering and Technology Management 12 (1/2), 1995, pp. $27-55$.

[49] S. Smithson, R. Hirschheim, Analysing information systems evaluation: another look at an old problem, European Journal of Information Systems 7 (3), 1998, pp. 158-174.

[50] T. Stratopoulos, B. Dehning, Does successful investment in information technology solve the productivty paradox? Information and Management 38 (2), 2000, pp. 103-117.

[51] F. Tayyari, D.E. Kroll, Total cost analysis of modern automated systems, in: H. Parsaei, T. Ward, W. Karwoski (Eds.), Justification Methods for Integrated Manufacturing Systems, Elsevier, New York, USA, 1990, pp. 234-241.

[52] M. Themistocleous, Z. Irani, Evaluating Enterprise Application Integration Technologies: A Novel Frame of References, European Journal of Operational Research, in press.

[53] J. Van Blois, Economic models: the future of robotic justification, in: Proceedings of the 13th ISIR/Robots 7 Conference, 17-21 April 1983. 
[54] C.A. Voss, Managing advanced manufacturing technology, International Journal of Operations and Production Management 6 (5), 1986, pp. 4-7.

[55] P. Weill, M. Broadbent, Leveraging the New Infrastructure: How Market Leaders Capitalize on IT, Harvard Business School Press, Boston, USA, 1998.

[56] O.W. Wight, The Oliver Wight A-D Checklist for Operational Excellence, 1993.

[57] O.W. Wight, Manufacturing Resource Planning: MRPII, Oliver Wight Ltd., USA, 1994.

[58] R.K. Yin, Case Study Research: Design and Methods, Applied Social Research Methods Series, Vol. 5, Sage, USA, 1994.

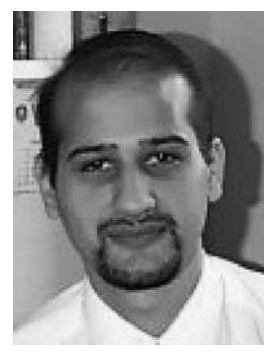

Zahir Irani is a senior lecturer in the Department of Information Systems and Computing, Brunel University, UK. Having previously worked as a project engineer, he retains close links with industry and is a non-executive director to a leading UK engineering company. Dr. Irani regularly reviews research proposals that are submitted to the European Union together with grant applications submitted to the National Science Foundation (NSF), USA. Dr. Zahir Irani is the director of a multi-disciplinary research group investigating information systems evaluation and integration, where he supervises eight $\mathrm{PhD}$ students. He is a Visiting Scholar to the University of Salford (UK), and a Visiting Professor at Deakin University (Australia) and at the Arab Academy of Science and Technology (Egypt). He is the editorin-chief of the Journal of Logistics Information Management and European Editor of the Business Process Management Journal. He has co-authored a teaching text-book on information systems evaluation, and written over 100 internationally refereed papers and received ANBAR citations of research excellence. He has spoken at conferences and guest seminars world-wide, and is internationally known for his scholarly work in the area of information systems evaluation and application integration. Further details can be found at http://www.brunel.ac.uk/ csstzni 